profile on the molars and very large incisors in comparison with the lateral incisors. All these characters are present on the S.indicus skull, and some at least are known to be present on other species such as Sivapithecus meteai and Sivapithecus punjabicus. They are all interpreted as being derived from the primitive hominoid condition and are thus specializations shared with the orang-utan. There are also many primitive characters shared with the orang-utan, such as the poor development of the supraorbital torus and the slope of the nose, and other characters like the great depth of the zygomatic bone that show greatest ressemblance to the orang-utan but are within the limits of variation of other hominoid species. Set against this list of characters are a few which show similarities with man. Of particular importance are the robustly built jaws, the lateral rotation of the canines and possibly low canine sexual dimorphism. Another similarity with man, the thick enamel and low cusp relief of the molars, is also shared with the orang-utan and cannot be considered diagnostic. The similarities with man are fewer in number and more strongly inter-related with each other than are the similarities with the orang-utan, and it is my belief that Sivapithecus must be seen as a relative of the orang-utan. It is shown thus on the accompanying cladogram.

It thus appears that Sivapithecus (including 'Ramapithecus') is part of the orang-utan clade, and both are more distantly related to man than are the African apes. In other words 'Ramapithecus' can no longer be considered as part of the human lineage but as part of the orang-utan lineage. The recognition of this relationship provides fossil evidence for the divergence date of the orang-utan, and the time span of 8-12 Myr for the species of Sivapithecus is certainly compatible with the molecular date of $10 \pm 3 \mathrm{Myr}$.

\title{
Measuring atmospheric gases and aerosols
}

\author{
from D.D. Davis, W.L. Chameides and C.S. Kiang
}

SOME nine months ago several of the findings of the National Science Foundation-supported Global Atmospheric Measurements on Tropospheric Aerosols and Gases programmme (GAMETAG) were critically reviewed in these columns ${ }^{1}$. As part of the planning group for this field sampling programme, we welcome efforts to bring GAMETAG results before a larger spectrum of the scientific community. We would now like to go on to clarify some points that were made earlier and to add new information from the most recently available results.

The first point involves the $\mathrm{NO} / \mathrm{HNO}_{3}$ GAMETAG measurements. Before the GAMETAG flights, the little information available on $\mathrm{NO}_{\mathrm{X}}$ in remote regions of the troposphere ${ }^{2-6}$ suggested that NO levels were in the $100-1,000$ p.p.t.v. (parts per $10^{12}$ by volume) range. The GAMETAG NO instrument, which had a lower detection limit of 50-60 p.p.t.v., gave readings which indicated that over thousands of miles of continental wilderness area and over large stretches of the open Pacific Ocean, NO levels were typically below that lower detection limit. The observations ${ }^{7}$ are the first to indicate that $\mathrm{NO}_{\mathrm{X}}$ levels in remote marine and northern continental troposheric air are much lower than previously believed. Subsequently, MacFarland et al. ${ }^{8}$ reported that NO levels in a limited region of the

D.D. Davis, W.L. Chameides and C.S. Kiang are in the School of Geophysical Sciences Georgia Institute of Technology, Atlanta, Georgia 30332 equatorial Pacific were in the $1-10$ p.p.t.v. range but the GAMETAG $\mathrm{HNO}_{3}$ observations were the first extensive remote-global tropospheric data base for this species. Of particular importance is the observation that lower levels of $\mathrm{HNO}_{3}$ are found in the marine boundary layer than in the middle free troposphere over extensive regions of the open Pacific Ocean. The results are in direct contradiction with all earlier predictions of $\mathrm{NO}_{\mathrm{X}} / \mathrm{NO}_{\mathrm{Y}}$ altitude profiles and show the need for significant revisions in the tropospheric nitrogen budget.

A second point involves new data now available on the question of photochemical activity over tropical and sub-tropical marine areas. Since Penkett wrote ${ }^{1}$, the data have been released in manuscript form and are shortly to appear in print. Direct $\mathrm{OH}$ observations show tropical mid-day marine boundary layer $\mathrm{OH}$ levels ranging from $\sim 2 \times 10^{6}$ up to a high of $1.5 \times 10^{7}$ molecules per $\mathrm{cm}^{3}$. It is argued by some that the absolute accuracy of the $\mathrm{OH}$ system may be in error by as much as a factor of two (the authors think this unlikely) but even if this were so and $\mathrm{OH}$ levels were assigned a value a factor of two lower, the conclusion that $\mathrm{OH}$ levels in the tropical marine boundary layer are typically quite high would still be clearly justified. It is estimated that the above observations imply a diurnally and seasonally averaged $\mathrm{OH}$ value of $\sim 2 \times 10^{6}$ molecules per $\mathrm{cm}^{3}$ for the tropical marine boundary layer. For spring and summer conditions, at sub-tropical latitudes, a similar diurnally averaged $\mathrm{OH}$ value of
$2 \times 10^{6}$ molecules per $\mathrm{cm}^{3}$ is estimated from our measurements. Mid free-tropospheric (that is, $5-6 \mathrm{~km}$ ) values over the above latitude range were typically a factor of two to three lower than those observed in the marine boundary layer. These $\mathrm{OH}$ values are significantly higher than the globally averaged value estimated by several investigators based on Northern/Southern Hemisphere $\mathrm{CH}_{3} \mathrm{CCl}_{3}$ measurements ${ }^{9-11}$. This result is consistent, however, with the higher than average levels of $\mathrm{H}_{2} \mathrm{O}$ and UV actinic radiation that normally characterize the above latitude zones. They further suggest that in the tropical marine boundary layer, $\mathrm{OH}$ radicals are very likely to be responsible for initiating the oxidation of numerous compounds released into the atmosphere in reduced oxidation states. Approximate photochemical lifetimes based on oxidation by $\mathrm{OH}$ at a level of $2 \times 10^{6}$ molecules per $\mathrm{cm}^{3}$ are $\mathrm{SO}_{2}$ (3.5 days), $\mathrm{CH}_{3} \mathrm{SCH}_{3}$ (1 day), $\mathrm{H}_{2} \mathrm{~S}$ (1 day), $\mathrm{NO}_{2}$ (0.7 day), $\mathrm{C}_{2} \mathrm{H}_{4}$ (0.7 day), $\mathrm{C}_{3} \mathrm{H}_{8}$ (0.2 day), $\mathrm{CO}$ (20 days) and $\mathrm{CH}_{3} \mathrm{Cl}$ (124 days). Virtually all these lifetimes are much shorter than those predicted from washout/rainout or dry deposition.

A final point concerns tropical marine tropospheric-photochemical activity and its relation to the GAMETAG observations which showed no direct evidence of any photochemical generation of $\mathrm{O}_{3}$. In spite of this observation, it is important to understand that the absence of $\mathrm{O}_{3}$ generation cannot be equated with the absence of free radical chemistry or the lack of importance of photochemistry, in general. It instead suggests that of the possible $\mathrm{HO}_{2}$ loss reactions (1)-(3):

$$
\begin{aligned}
& \mathrm{HO}_{2}+\mathrm{HO}_{2} \rightarrow \mathrm{H}_{2} \mathrm{O}_{2}+\mathrm{O}_{2} \\
& \mathrm{HO}_{2}+\mathrm{NO} \rightarrow \mathrm{OH}+\mathrm{NO}_{2} \\
& \mathrm{HO}_{2}+\mathrm{CH}_{3} \mathrm{O}_{2} \rightarrow \mathrm{CH}_{3} \mathrm{OOH}+\mathrm{O}_{2}
\end{aligned}
$$

reaction (2), under tropical marine boundary layer conditions, is unsuccessful in competing with reactions (1) and (3). This result is a direct consequence of the previously described low levels of NO in the tropical marine boundary layer. It should be stressed, however, that the absence of $\mathrm{O}_{3}$ production does not preclude the use of marine tropical areas of the world as future field sampling sites for studying freeradical tropospheric chemistry. In fact, the simplified chemistry of this region, resulting from highly reduced levels of hydrocarbons and their oxygenated analogues, should present the best opportunity for unravelling many key aspects of tropospheric chemistry.

\footnotetext{
Penkett, S.A. Nature 290, 631 (1981)

2. Noxn, J.F. Science, 189, 549 (1975)

3. Lodge, J.P. \& Pate, J.B. Science 153, 408 (1966).

4. Georgii, I.H.W., \& Jost, D. Pure appl. Geophys. 59,217 (1964).

5. Moore, H. Tellus 26, 169 (1974)

6. Cox, R.A. Tellus 29, 356 (1977)

7. Schiff, H.I., Pepper, D \& Ridley, B.A. J. geophys. Res. 84, 7895 (1979).

8. MacFarland M et al Geophys. Res. Lett 6, 1605 (1979). 9. Singh, H.B. Geophys. Res. Lett. 4, 453 (1977).

10. Crutzen, P.J. \& Fishman, J. Geophys. Res. Let 4, 321 (1977).

11. Chameides, W.L. \& Tan, A. J. geophys. Res. 86, 5209 (1981).
} 